\title{
First report of Masseeëlla capparis in Australia
}

\author{
J. R. Liberato • A. R. McTaggart • R. G. Shivas
}

Received: 15 April 2012 / Accepted: 18 December 2013 /Published online: 9 January 2014

(C) Australasian Plant Pathology Society Inc. 2014

\begin{abstract}
The rust fungus Masseeëlla capparis is reported for the first time in Australia on Flueggea virosa (Phyllanthaceae). This is the first species of Masseeëlla found in Australia. The rust is described and illustrated from Australian specimens. A discussion on species of Masseeëlla is provided. A reconstructed phylogeny with the Large Subunit region of ribosomal DNA indicated that Masseeëlla has an affinity with the Phakopsoraceae.
\end{abstract}

Keywords Phakopsoraceae · Phylogeny · Pucciniales ·

Northern Territory · Queensland

Flueggea virosa (Euphorbiaceae sensu lato or Phyllanthaceae) comprises two subspecies; subsp. virosa, which is widespread in the tropics from Africa to south east Asia, and subsp. melanthesoides, which occurs in New Guinea and northern Australia (Wheeler 1992, Barker and van Welzen 2010). Three specimens of rust fungi on $F$. virosa subsp. melanthesoides from the Northern Territory and Queensland were identified as Masseeëlla capparis based on morphology,

J. R. Liberato $(\bowtie)$

Department of Primary Industry and Fisheries, Plant Pathology Section, GPO Box 3000, Darwin, Northern Territory 0801, Australia e-mail: jose.liberato@nt.gov.au

\section{A. R. McTaggart}

Queensland Alliance for Agriculture and Food Innovation, The University of Queensland, Ecosciences Precinct, GPO Box 267, Brisbane, Queensland 4001, Australia

R. G. Shivas

Plant Pathology Herbarium, Biosecurity Queensland, Department of Agriculture, Fisheries and Forestry, GPO Box 267, Brisbane,

Queensland 4001, Australia according to the descriptions given by Massee (1892), Dietel (1895), Mishra and Nema (1973) and Kumar et al. (1978). A detailed description of $M$. capparis based on the Australian specimens follows.

Masseeëlla capparis (Hobson bis in Cooke) Dietel [as 'capparidis'] (Figs. 1 and 2)

Berichte der Deutschen Botanischen Gesellschaft 13: 334 (1895)

E Cronartium capparis Hobson bis in Cooke [as 'capparidis'], Grevillea 14: 89 (1886). Holotype on Capparis sp. [probably Flueggea virosa, fide Mundkur and Thirumalachar (1946: 12)], India, Karnataka, Belgaum, coll. Major-General Hobson, K; fide Mundkur and Thirumalachar (1946: 11).

= Masseeëlla flueggeae Syd. in Syd. \& Petrak, Annales Mycologici 26: 424 (1928). Holotype on Flueggea virosa, Philippines; fide Mundkur and Thirumalachar (1946: 11).

Spermogonia, aecia and uredinia not seen. Telia amphigenous, mostly on the upper leaf surface, immersed, solitary or gregarious, extruding a smooth curled column, light to dark reddish brown, up to $2 \mathrm{~cm}$ long and 30-300 $\mu \mathrm{m}$ wide, composed of teliospores embedded in a dense hyaline matrix that becomes gelatinous when moist. Teliospores one-celled, rounded to pyriform, slightly angular, often conspicuously truncate at the base, sessile, non-catenulate, $21-37(\overline{\mathrm{x}}=29.1$ $, \mathrm{SD}=3.2, n=100) \times 17-26(\overline{\mathrm{x}}=21.3, \mathrm{SD}=1.9, n=100) \mu \mathrm{m}$, length/width ratio $1.0-2.3(\overline{\mathrm{x}}=1.4)$, golden brown, wall (2-) $3-5.5 \mu \mathrm{m}$ thick, longitudinally striate, commonly rounded at the apex, with a prominent apical germ pore.

Specimens examined: on Flueggea virosa subsp. melanthesoides (F. Muell.) G.L. Webster: AUSTRALIA, NORTHERN TERRITORY: Mataranka, 24 June 2010, $14.92249^{\circ} \mathrm{S}, 133.13392^{\circ} \mathrm{E}, H$. Wallace (DNAP 4605), III; 
Fig. 1 Coiled hair-like extrusions of teliospores of Masseeëlla capparis on Flueggea virosa subsp. melanthesoides (dried specimens). a on the upper leaf surface (DNAP 4605). b-d on the lower leaf surface (seen under stereo microscope). Bar $=0.5 \mathrm{~mm}$. b DNAP 4627. c-d DNAP 4489
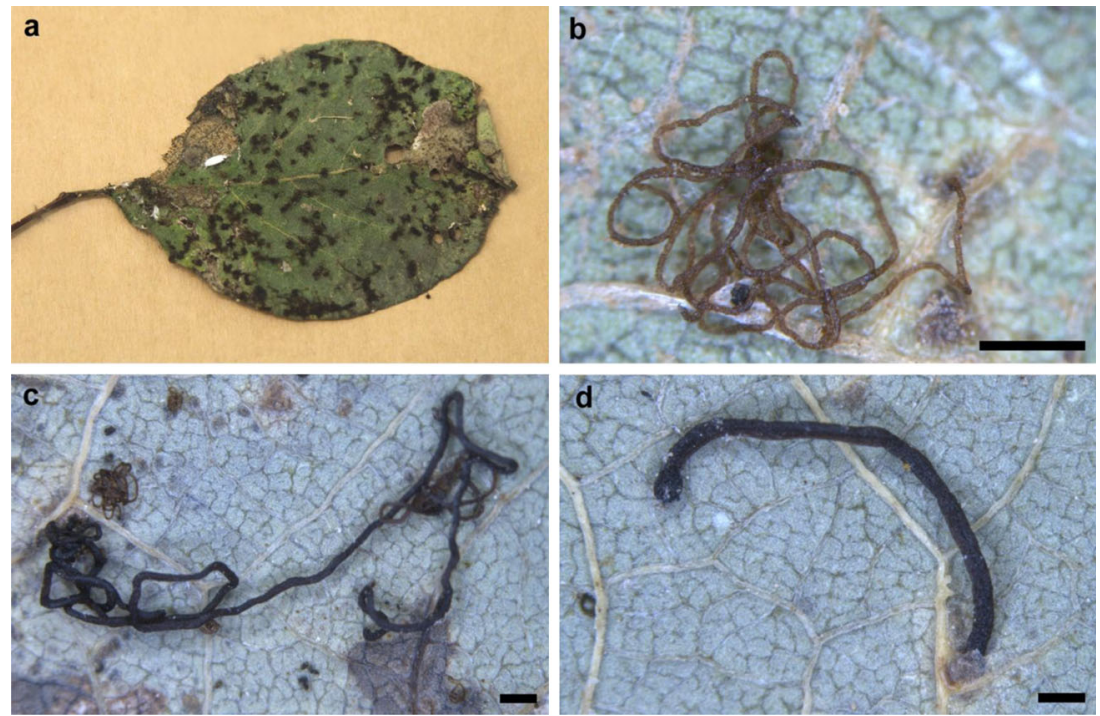

loc. cit., 19 July 2010, H. Wallace(DNAP 4489, BRIP 53724), III; 10 May $2011,14.92173^{\circ} \mathrm{S}, 133.13588^{\circ} \mathrm{E}, H$. Wallace (DNAP 4627, BRIP 57656), III; Victoria River, 20 April 2012, V. Andjic, M. Butt, K. Ireland, C. Doungsa-ard, A.R. McTaggart, R. Berndt, V. Faust-Berndt, M.D.E. and R.G. Shivas (BRIP 56845), III; Katherine, same date and coll., (BRIP 56844), III. QUEENSLAND: Musgrave, $14.8625^{\circ} \mathrm{S}$, $143.09717^{\circ}$ E, 15 July 1999, R.G. Shivas and M. Gunther (BRIP 26745), III. On Flueggea virosa (Roxb. ex Willd.) Royle subsp. virosa: ZAMBIA: Palm Island, Livingstone, 30 Apr. 1963, K.A. Pirozynski (IMI 112481, BRIP 18791), III; Chilanga, Lusaka, 15 July 1963, K.A. Pirozynski(IMI 115337, BRIP 18795), III.

Hosts: on Euphorbiaceae: Flueggea spp. and Suregada multiflora (Mishra and Nema 1973, as Gelonium multiflorum).

Distribution: Australia, India (Cooke 1886, Massee 1892, Dietel 1895, Singh and Singh 1967, Mishra and Nema 1973, Kumar et al. 1978), Pakistan (Khalid et al. 2010), South Africa (Doidge 1939), Philippines (Sydow and Petrak 1928, Arthur \& Cummins 1936, Cummins 1937) and Zambia.

The aecial stage of $M$. capparis is unknown. Aecia found on leaves of $F$. virosa in India (Singh and Singh 1967) and the Philippines (Cummins 1937, as M. flueggeae) were not connected with telia of $M$. capparis. Doidge (1939) reported the uredinial stage of $M$. capparis (as $M$. flueggeae) on $F$. virosa in South Africa as Uredo brideliae (Henn. \& A. Evans) Doidge, which is an illegitimate name as it is a nomenclatural homonym of Uredo brideliae Koord. This specimen did not possess telia. Sydow and Petrak (1928) considered the urediniospores and teliospores described in the diagnosis of $M$. flueggeae belonged to the same fungus as both spore forms occurred together on some of their specimens.
There are six additional species of Masseeëlla that have been described, including $M$. flueggeae, which is a synonym of $M$. capparis. The remaining five species are (i) M. breyniae Thirum. on Breynia vitis-idaea (Phyllanthaceae) in India (Thirumalachar 1943a, as Breynia rhamnoides); (ii) $M$. narasimhanii Thirum. on $F$. leucopyrus and $F$. virosa in India (Thirumalachar 1943b, Singh and Singh 1967, Kalode and Patil 1978); (iii) M. ciferrii Ciccar. on Berchemia yemensis (Rhamnaceae) in Ethiopia (Ciccarone 1951); (iv) M. putranjivae T.S. Ramakr. on Putranjiva roxburghii (Putranjivaceae) in India (Ramakrishnan 1957) and (v) M. terminaliae (Henn.) Patw. on Terminalia chebula (Combretaceae) in India (Patwardhan 1964).

Spermogonia, aecia, uredinia and telia were described for $M$. breyniae, $M$. narasimhanii and $M$. putranjivae. The connection between spermogonia/aecia and uredinia/telia was demonstrated for $M$. breyniae through experimental inoculation, which showed this rust was a macrocyclic and autoecious (Thirumalachar 1943a). The teliospores of species of Masseeëlla are morphologically similar. Arthur \& Cummins (1936) reported M. flueggeae from Philippines as having teliospores finely and longitudinally striate as in $M$. capparis. According to Ciccarone (1951), M. ciferrii does not differ morphologically from $M$. capparis and was described as a new species on the basis that the host belonged to a different family (Rhamnaceae). Furthermore M. narasimhanii was described from $F$. leucopyrus, the same host genus as $M$. capparis. Whereas $M$. narasimhanii has teliospores longitudinally striate and with similar size and colour to ones of $M$. capparis, there is a possibility of synonymy among these Masseeëlla species, which needs molecular phylogenetic analysis and pathogenicity experiments to be verified. 
Fig. 2 Teliospores of Masseeëlla capparis (DNAP 4489).

a-d Spore tendrils. Bar $=50 \mu \mathrm{m}$; $\mathbf{e}-\mathbf{h}$ Bar $=20 \mu \mathrm{m}$. a-b mounted in lactic acid and not heated. c mouted in water. $\mathbf{d}-\mathbf{h}$ mounted in lactic acid and gently heated
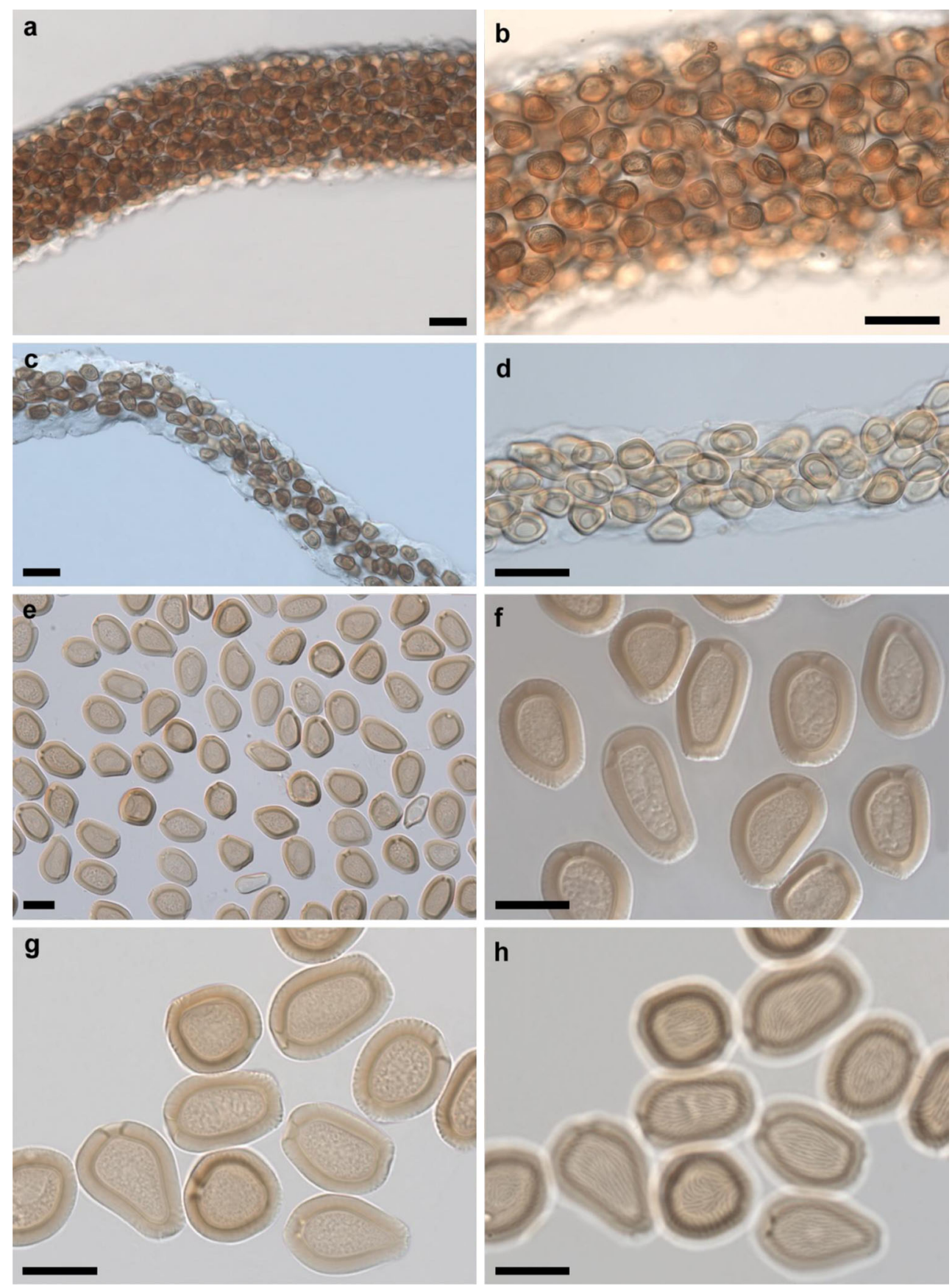

The phylogenetic position of Masseeëlla within the Pucciniales is uncertain (Cummins and Hiratsuka 2003) and there is no molecular data available for that genus. To establish the phylogenetic placement of $M$. capparis, DNA was extracted from one specimen (BRIP 56844) according to the protocol described by Aime (2006) using the UltraClean Plant DNA Isolation Kit (MoBio Laboratories, Solana Beach, CA, USA). The ITS2-LSU region was amplified with Rust2inv (Aime
2006)/LR7 (Vilgalys and Hester 1990). The novel sequence data was deposited in GenBank (accession number JX136798).

A reconstructed phylogeny of the Pucciniales based on the Large Subunit (LSU) dataset of Minnis et al. (2012) placed Masseeëlla as sister to Phakopsora, within the Phakopsoraceae with strong phylogenetic support (0.98 aRLT, $95 \%$ bootstrap) (Aime 2006) (Fig. 3). Further analyses 


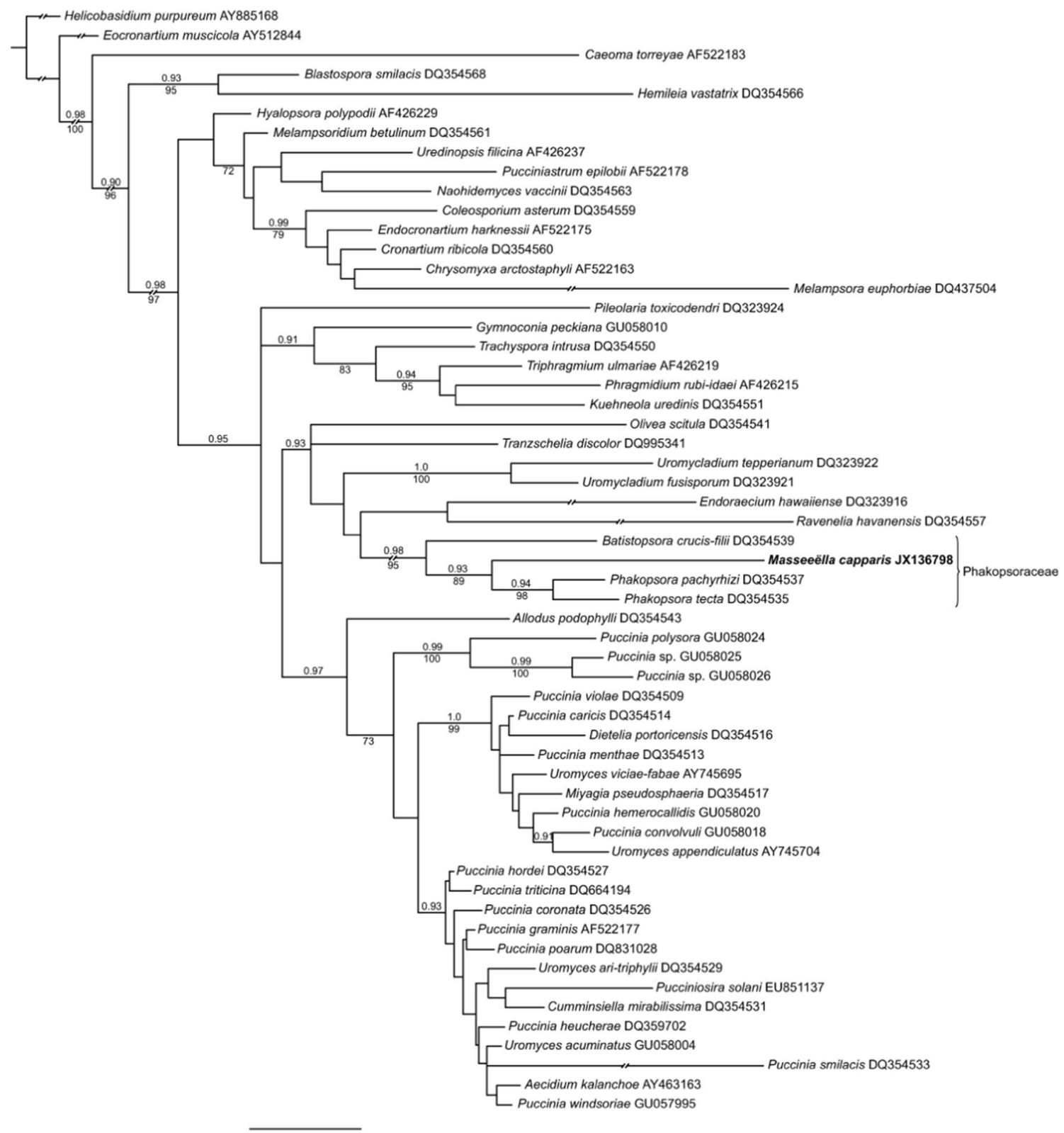

0.04

Fig. 3 Phylogram of main families in the Pucciniales obtained from a maximum likelihood search in PhyML with the LSU region of rDNA (dataset of Minnis et al. 2012). aRLT support values $(>0.90)$ from an SPR search in PhyML above nodes, bootstrap values $(>70 \%)$ from a

including the Small Subunit region of rDNA may help to confirm the familial position of Masseeëlla.

Acknowledgments The authors thank the Northern Territory Herbarium for identification of the plant species and Dr Reinhard Berndt (ETH Zürich, Switzerland) for translation of some of Sydow's comments. The junior authors would like to thank Dr Glynn Maynard (Commonwealth Department of Agriculture, Fisheries and Forestry) for making funds available through the Advanced Diagnosticians Development framework (ADDf) program that facilitated part of this study. This work was partly maximum likelihood bootstrap search with 1,000 replicates in RAxML shown below nodes. GTRGAMMA was specified as the model of evolution in both programs

funded by the Australian Biological Resources Study grant number RFL212-33.

\section{References}

Aime MC (2006) Toward resolving family-level relationships in rust fungi (Uredinales). Mycoscience 47(3):112-122 
Arthur JC, Cummins JB (1936) Philippine rusts in the Clemens collection 1923-1926, II. Philippine Journal of Science, Section C Botany 61(4):463-488

Barker C, van Welzen PC (2010) Flueggea (Euphorbiaceae s.l. or Phyllanthaceae) in Malesia. Syst Bot 35:541-551

Ciccarone A (1951) Primo contributo alla conoscenza dei Micromiceti dell'Africa orientale. Mycopathol Mycol Appl 5:208-235

Cooke MC (1886) Some exotic fungi. Grevillea 14(71):89-90

Cummins GB (1937) Studies in the Uredinales of the Philippines. Annales Mycologici 35:98-105

Cummins GB, Hiratsuka Y (2003) Illustrated Genera of Rust Fungi. 3 edn. American Phytopathological Society, St. Paul

Dietel P (1895) Drei neue Uridineengattungen: Masseeella, Phakopsora und Schizospora. Ber dtsch bot ges 13:332-335

Doidge EM (1939) South African rust fungi, III. Bothalia 3(4):487-512

Kalode MB, Patil BV (1978) Critical notes on some plant rusts from India. Sydowia 31:81-86

Khalid AN, Afshan NS, Elahi H (2010) Masseeella flueggeae on Flueggea virosa, a new record for Pakistan. Mycotaxon 114: 453-457

Kumar A, Bhansali RR, Soni SR (1978) Securinega leucopyrus (Willd.) Muell. a new host of Masseeella in Indian arid zone. Transactions of Indian Society of Desert Technology and University Centre of Desert Studies 3(1):41-42

Massee G (1892) Notes on fungi in the royal herbarium Kew. Grevillea 21:33-35
Minnis D, McTaggart AR, Rossman A, Aime MC (2012) Taxonomy of mayapple rust: the genus Allodus resurrected. Mycologia 104(4):942-950

Mishra RP, Nema KG (1973) Gelonium multiflorum A. Juss a new host for Masseeella capparidis (Hobson) Diet. JNKVV Res J Jarwaharlal Nehru Krishi Vishwa Vidylaya 7(4):285-286

Mundkur BB, Thirumalachar MJ (1946) Revisions of and additions to Indian fungi. Mycological Papers 16. IMI, Kew, 27pp

Patwardhan PG (1964) The perfect stage of Uredo terminaliae P. Henn. Mycopathol Mycol Appl 24:172-174

Ramakrishnan TS (1957) Notes in some fungi. Proceedings of the Indian Academy of Sciences, Section B 45(4):176-180

Singh H, Singh BV (1967) On some Indian species of Masseeella. Mycopathologia 33(2):193-199

Sydow H, Petrak F (1928) Micromycetes Philippinenses. Annales Mycologici 26:414-446

Thirumalachar MJ (1943a) Masseeella breyniae, a new species of rust. New Phytol 42(1):45-48

Thirumalachar MJ (1943b) Masseeella narasimhanii, a new species of rust on Flueggea leucopyrus Willd. Proceedings of the Indian Academy of Sciences, Section B 18(2):36-40

Vilgalys R, Hester M (1990) Rapid genetic identification and mapping of enzymatically amplified ribosomal DNA from several Cryptococcus species. J Bacteriol 172(8):4238-4246

Wheeler JR (1992) Euphorbiaceae in Wheeler JR (ed.) Flora of the Kimberley region. Department of Conservation and Land Management, Perth, pp 589-629 